Research Article

\title{
Emergency Trench Shoring and Rescue: A Simplified Method for Calculating Lateral Earth Pressures
}

\author{
Oliver-Denzil S. Taylor ${ }^{1}{ }^{1}$ and S. Marie LaBaw ${ }^{2}$ \\ ${ }^{1}$ U.S. Army Engineer Research and Development Center, Geotechnical and Structures Laboratory, Vicksburg, MS 39180, USA \\ ${ }^{2}$ Office of Fire Code Compliance, Montgomery County Department of Permitting Services, 255 Rockville Pike, Rockville, \\ MD 20850, USA
}

Correspondence should be addressed to Oliver-Denzil S. Taylor; oliver.d.taylor@usace.army.mil

Received 10 July 2018; Revised 30 August 2018; Accepted 13 September 2018; Published 25 October 2018

Guest Editor: Jian Sun

Copyright () 2018 Oliver-Denzil S. Taylor and S. Marie LaBaw. This is an open access article distributed under the Creative Commons Attribution License, which permits unrestricted use, distribution, and reproduction in any medium, provided the original work is properly cited.

\begin{abstract}
Emergency trench shoring design for rescue operations has no reliable standard to determine lateral earth pressures. As a result, the first responder community is forced either to rely predominantly on either "rule-of-thumb" methods or similarly to assume the OSHA 29 CFR for Type C soil to determine a "worst-case scenario." However, the use of generalized methods, i.e., the C-80, is not officially supported by OSHA standards, which are overly conservative and do not reflect the observations of actual trench surface failures. Additionally, the shoring system requirements can be unnecessarily prohibitive in short-term emergency operations. The current "rule-of-thumb" method used by first responders underestimates braced earth pressures for weak sandy soils and is not recommended for continued use. Therefore, a simplified soil mechanics-based lateral earth pressure framework, the "T$\mathrm{L}$ method," that accurately represents actual earth pressures based on the in situ soil failure conditions, is presented. The T-L method is validated against Coulomb earth pressure theories and braced excavation thrust pressures for Type C soils. The results indicate a significant reduction in estimated lateral earth pressures which are typically required for a standard construction shoring system design, while providing an adequate and safe emergency rescue shoring standard for first responders.
\end{abstract}

\section{Introduction}

First, responders accept the US Occupational Safety and Health Administration (OSHA) Type C soil as the "worstcase" material and is defined as follows [1, 2]:

(i) Cohesive soil with an unconfined strength of less than 0.5 tsf $(47.9 \mathrm{kPa})$

(ii) Weak granular soil, including gravel, sand, and loamy sand

(iii) Submerged soil or soil from which water is actively weeping.

OSHA provides labour practice standards relating to permanent trench shoring and defines the minimum lateral earth pressure shoring requirements, $P_{C-\chi}$, for Type $\mathrm{C}$ soil, in units of pounds per square foot (psf), as follows [2]:

$$
P_{C-\chi}=\chi(H)+72 \text {, }
$$

where $H$ is the depth of the trench (ft) and the constant 72 is the representative of a light $2 \mathrm{ft}(0.6 \mathrm{~m})$ surcharge load. The $\chi$ multiplier relates $H$ to the lateral earth-pressure at the base of the excavation. Table C-1.3 in OSHA [2] uses $\chi$ of 80 but does not give the derivation or the limitations of use; instead, it requires a uniform earth pressure distribution based on the base trench pressure. Equation (1) is typically referred to by the soil type and the $\chi$ variable, e.g., C- 80 method, and is used herein. OSHA [3] cautioned against using Equation (1), despite Equation (1) being the standard, stating that shoring should be designed by a "competent person." This left first responders without a simple, rapid, and accurate standard from which earth pressures could be calculated for rapid rescue shoring operations where time is critical and "competent persons" may not be readily available. Consequently, "rule-of-thumb" methods, including Equation (1), 
have formed an ad hoc "local standard" emergency shoring design guidance. The common "rule-of-thumb," $P_{\mathrm{rt}}$, calculation, currently used is [1]

$$
P_{\mathrm{rt}}=0.33(100 \mathrm{pcf})(H)=33.33(H) \text {. }
$$

The unit weight of 100 pounds per cubic foot (pcf) $\left(15.7 \mathrm{kN} / \mathrm{m}^{3}\right)$ is unrealistic for a natural soil, e.g., typical quartz-silica sand has an unsaturated unit weight of approximately $120 \mathrm{pcf}(18.9 \mathrm{kN} / \mathrm{m} 3)$ [4, 5]. Moreover, the functional form is incorrect for Coulomb theory and braced excavation design [5-9].

Coulomb theory describes the total horizontal pressure, $P_{\mathrm{h}}$, on a unit width of a vertical plane extending from the surface to a depth, $H$, as

$$
P_{\mathrm{h}}=\frac{1}{2} k_{i} \gamma H^{2} \pm S_{\mathrm{u}} H \sqrt{k_{i}} \approx \frac{1}{2} k_{i} \gamma H^{2} \text { (for Type C soils), }
$$

where $\gamma$ is the bulk unit weight and $S_{\mathrm{u}}$ is the undrained shear strength. For Type C soils, the undrained shear strength is assumed negligible and can be conservatively approximated in Equation (3). The earth pressure coefficient, $k_{i}$, can be expressed as at-rest, $k_{0}$; active, $k_{\mathrm{a}}$; or passive, $k_{\mathrm{p}}$.

Over the width of a standard emergency trench rescue shoring panel, $4 \mathrm{ft}(1.2 \mathrm{~m})$, the resultant active force, $Q_{h}$, is

$$
Q_{\mathrm{h}}=2 k_{i} \gamma H^{2} \text {. }
$$

A retaining structure is required to resist $k_{\mathrm{a}}$ conditions where $k_{\mathrm{a}}$ is

$k_{\mathrm{a}}=\left\{\frac{\csc (\beta) \sin (\beta-\phi)}{\sqrt{\sin \left(\beta+\phi_{\mathrm{w}}\right)}+\sqrt{\left(\sin \left(\phi+\phi_{\mathrm{w}}\right) \sin (\phi-i)\right) / \sin (\beta-i)}}\right\}^{2}$,

where $\beta$ is the inclination of the shoring panel, $\phi$ is the soil friction angle, $\phi_{\mathrm{w}}$ is the soil-panel friction, and $i$ is the ground inclination. For emergency shoring, it can be assumed that $\phi_{\mathrm{w}}$ is negligible and shoring panel installation is near vertical, $\beta=90^{\circ}$.

The quantifications of $\phi, \gamma, i$, and pressure distributions are not practical, beyond the training of most first responders, and are grossly assumed, e.g., Equations (1) and (2). Actual excavation failures can vary significantly in both size and shape depending on the heterogeneity of the soil, presence of weak soil lenses, and degree of saturation. Therefore, a simplified approach to trench failure earth pressures is derived from the actual failure surface at the operation site, i.e., the T-L method. By using the actual failure surface, the in situ effects can be implicitly accounted for.

\section{Derivation of Simplified Earth Pressures (T-L Method)}

Rescue shoring consists of panel sections with a minimum of two shores per panel. The T-L method quantifies a required shoring strut resistance, $R_{\mathrm{T}-\mathrm{L}}$, to a lateral earth pressure resultant, Equation (3), that acts on the centre of a section of the shoring panel, typically one-half of the panel area, and is developed specifically for emergency rescue operations.

The T-L method bulk density for a saturated Type C soil, $\gamma_{\mathrm{T}-\mathrm{L}}$, is derived conservatively from the following:

$$
\begin{aligned}
\gamma_{\mathrm{d}} & =\frac{G_{\mathrm{s}} \gamma_{\mathrm{w}}}{1+e}, \\
\gamma_{\mathrm{d}} & =\frac{\gamma_{\mathrm{w}} S}{\omega+\left(S / G_{\mathrm{s}}\right)}, \\
\gamma_{\mathrm{T}-\mathrm{L}} & =(1+\omega) \gamma_{\mathrm{d}},
\end{aligned}
$$

where $\gamma_{\mathrm{d}}$ is the dry unit weight of the soil, $\gamma_{\mathrm{w}}$ is the unit weight of water, $e$ is the void ratio, $\omega$ is the gravimetric water content, $S$ is the degree of saturation, and $G_{s}$ is the specific gravity.

Taylor et al. $[10,11]$ determined that unconfined sand, e.g., soil at or near the excavation face, fails at a degree of saturation of approximately $73 \%$ irrespective of the soil's density. Therefore, it is assumed that the maximum degree of saturation in the T-L method derivation is also $73 \% . G_{s}$ is typically between 2.62 and 2.76, depending on the soil mineralogy [5]. A typical specific gravity of quartz-feldspar sand, 2.67, is used herein. Conservatively, the void ratio, $e$, is assumed as the median minimum void ratio for granular soils, 0.375 [12]. Solving Equations (6)-(8), $\gamma_{\mathrm{T}-\mathrm{L}}$, is $133.3 \mathrm{pcf}$ $\left(20.9 \mathrm{kN} / \mathrm{m}^{3}\right)$.

The soil's $\phi$ ranges significantly depending on grain size and shape, mineralogy, confinement, saturation, etc. $[5,10,11,13-16]$. It is not practical to estimate a potential in situ $\phi$ in a rescue operation as the actual failure surface is rarely equivalent to the theoretical failure surface suggested in design earth pressure calculations, e.g., Coulomb [17]; OSHA [2]; Lancellotta [18]; and Paik and Salgado [19]; therefore, the maximum lateral extent of the actual failure, $L$ (Figure 1 ), is used to determine the earth pressure geometry. In emergency operations, specific sections of the trench face have failed with most of the trench face still intact, i.e., quasistable and "at-rest."

While an open excavation that is "at rest" does not exhibit a net horizontal stress without movement, the T-L method considers an "at rest" or $k_{0}$ condition of $k_{0}=0.50$ as a conservative measure for cohesionless soil at or near the failed trench section. Cohesive soils can have $k_{\mathrm{a}}$ values exceeding the assumed $k_{0}$ values; however, as shown in Equation (3), the undrained shear strength reduces the net pressure compared to a weak sandy material even for Type C clays. The assumption of $k_{0}=0.50$ is equivalent to sandy material with a friction angle of $30^{\circ}$ translating to a lateral pressure 1.5 times greater than the active case for a level ground.

Thus, the required lateral resistance is

$$
R_{\mathrm{T}-\mathrm{L}}^{s}=\frac{1}{n_{\mathrm{s}}} w d L_{i} \gamma_{\mathrm{T}-\mathrm{L}} k_{0}
$$

where $R_{\mathrm{T}-\mathrm{L}}^{s}$ is the resistance of a single strut acting at the centre of one-half of the area of the shoring panel; $n_{\mathrm{s}}$ is the standard number struts per standard rescue panel, and in the United States, there are typically two struts per shoring panel; $w$ and $d$ are the standard dimensions, width, and depth, respectively, of the rescue shoring panels; and $L_{i}$ is the 


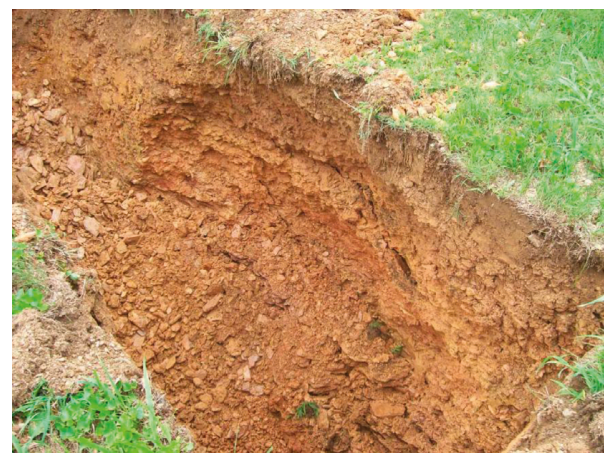

(a)

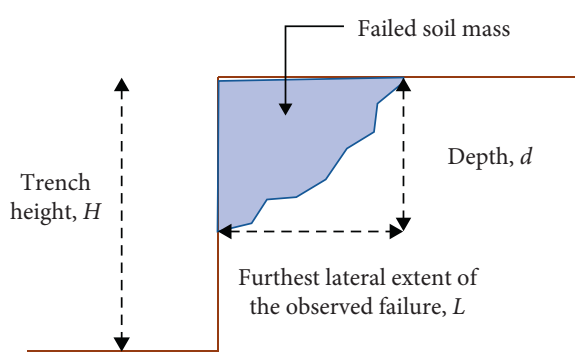

(b)

FIgURE 1: (a) Typical trench failure profile for Type C soil: (a) observed in situ with weak lenses and soil heterogeneity; (b) profile of failure shape with failure extents for derivation of the T-L method.

lateral extent of the failed mass in units of feet $(\mathrm{ft})$ or meters (m) denoted by the subscript $i$. In the United States, emergency rescue shoring panels are of the same specific standard nominal dimension as plywood sheeting, $4 \mathrm{ft} \times 8 \mathrm{ft}$. The European standard for nominal plywood sheeting is the SI equivalent of $125 \mathrm{~cm} \times 250 \mathrm{~cm}$ or $1.25 \mathrm{~m} \times 2.50 \mathrm{~m}$.

For standard nominal rescue shoring dimension with two struts per panel, Equation (9) reduces to

$$
\begin{aligned}
& R_{\mathrm{T}-\mathrm{L}}^{\mathcal{s}}=1.0625 L_{\mathrm{ft}} \approx 1.1 L_{\mathrm{ft}}(\mathrm{kips}), \\
& R_{\mathrm{T}-\mathrm{L}}^{s}=16.328 L_{\mathrm{m}} \approx 16.4 L_{\mathrm{m}}(\mathrm{kN}) .
\end{aligned}
$$

In rare cases in which $L_{i}$ is indeterminate or the trench rescue operation is not the result of a collapsed excavation face, the maximum calculated resistance for a given trench depth in Table 1 ( $L_{\max }=0.7 \mathrm{H}$ corresponding to an effective friction angle of $20^{\circ}$ material) should be used. The total shoring system resistance is

$$
R_{\mathrm{T}-\mathrm{L}}=n R_{\mathrm{T}-\mathrm{L}}^{s}
$$

where $n$ is the number of struts for a given trench depth. It must be noted that $n$ is not equivalent to $n_{\mathrm{s}}$ in Equation (9). Table 1 tabulates the T-L resistance, Equations (10) and (11), for a range of $L$ and trench depths.

The results of Equation (11) were compared to those of Equations (4) and (5) and are shown in Table 2. The "worstcase" soils range from a weak saturated clayey sand or sandy loam $\left(\phi=20^{\circ}\right.$ and $\gamma=120 \mathrm{pcf}$ or $\left.18.9 \mathrm{kN} / \mathrm{m}^{3}\right)$ to a heavy dense sand $\left(\phi=40^{\circ}\right.$ with $\gamma=130 \mathrm{pcf}$ or $\left.20.4 \mathrm{kN} / \mathrm{m}^{3}\right)$ [5]. The ground behind the trench face cannot always be the assumed level; therefore, $i$ is included in Equation (5) and Table 2. Table 2 illustrates that the maximum $Q_{\mathrm{h}}$ correlates to the weak soil despite the lower bulk density; therefore, the maximum $L_{i}$ in the T-L method (Table 1) corresponds to this condition and is used in Table 2 for an equivalent comparison. The largest $Q_{\mathrm{h}}$ occurs when $i$ is $30^{\circ}$; however, in no case was a failure condition, $R_{\mathrm{T}-\mathrm{L}}<Q_{h}$, observed suggesting that Equation (11) adequately resists the "worst-case" Coulomb earth pressures.

Emergency shoring systems more closely resemble braced excavations, thereby requiring shoring design to use a "reasonable" earth thrust pressure distribution [5-9, 20-24]. The actual stress distribution for braced excavations varies significantly compared to that of Coulomb theory and between shallow (less than $6.1 \mathrm{~m}$ ) and deep (greater than $6.1 \mathrm{~m}$ ) excavations $[24,25]$. The majority of the research into braced excavation, i.e., Terzaghi and Peck [8], Peck [6], Tschebotarioff [9], Wang [22], Karlsrud and Andresen [21], Blackburn and Finno [20], is limited to deep excavation sites and are not necessarily applicable in emergency trench rescue operations [24, 25]. Yokel [23], LaBaw [25], and LaBaw and Aggour [24] are the only research efforts, known to the authors, on shallow braced excavations. Yokel [23] uses a theoretical rectangular earth pressure envelope for shallow excavations that is equivalent to Equation (3) wherein the resulting total thrust is in excess of Peck [6]. However, recent research has shown that the actual earth pressures acting on shallow braced excavations are significantly reduced when the structural elements of the shoring system, e.g., strongbacks and panels, are considered [24, 25]. Applying a minimum reduction of 53\% [24] to account for the thinnest possible panel, the thrust pressures calculated by Yokel [23] are reduced to those of Peck [6]. Furthermore, LaBaw and Aggour [24] illustrate that the actual earth pressure distribution is nonuniform behind the panel face. Thus, the total thrust pressure can be conservatively approximated using the theoretical rectangular distribution of Yokel [23] at a maximum thrust pressure calculated by Peck [6].

However, the total thrust against the excavation bracing does not necessarily differ from Equation (3) and should be stable from a global design scale if the active Coulomb pressures can be resisted [5]. Each structural member cannot be designed solely based on the earth pressure distribution as the central shores must be able to withstand thrust pressures [5-9]. Peck [6] suggests that a maximum thrust pressure for a sand, $P_{\mathrm{t}}^{\mathrm{p}}$, is

$$
P_{\mathrm{t}}^{\mathrm{p}}=0.65 \gamma k_{\mathrm{a}} H
$$

Tschebotarioff [9] differentiates between permanent and temporary braced excavations where the maximum temporary excavation thrust pressure, $P_{\mathrm{t}}^{\mathrm{T}}$, for sand, is

$$
P_{\mathrm{t}}^{\mathrm{T}}=0.25 \gamma H \text {. }
$$

It is not practical in rescue operations to calculate different strut pressures with depth; therefore, the T-L method conservatively requires that all struts must resist the maximum thrust pressure. This assumption is similar to the 
TABLE 1: T-L method resistance calculations as a function of the lateral extent of the observed failure.

\begin{tabular}{|c|c|c|c|c|c|c|c|c|c|c|c|c|c|}
\hline \multirow{3}{*}{\multicolumn{2}{|c|}{$\begin{array}{c}\text { Furthest } \\
\text { lateral } \\
\text { extent of } \\
\text { observed } \\
\text { failure, } L\end{array}$}} & \multicolumn{12}{|c|}{ T-L method resistance calculations } \\
\hline & & \multicolumn{6}{|c|}{$R_{\mathrm{T}-\mathrm{L}}(\mathrm{kips})$} & \multicolumn{6}{|c|}{$R_{\mathrm{T}-\mathrm{L}}(\mathrm{kN})$} \\
\hline & & \multicolumn{5}{|c|}{ Trench depth } & $R_{\mathrm{T}-\mathrm{L}}^{s}$ & \multicolumn{5}{|c|}{ Trench depth } & \multirow[t]{2}{*}{$R_{\mathrm{T}-\mathrm{I}}^{s}$} \\
\hline $\mathrm{ft}$ & $\mathrm{m}$ & $4 \mathrm{ft}$ & $8 \mathrm{ft}$ & $12 \mathrm{ft}$ & $16 \mathrm{ft}$ & $20 \mathrm{ft}$ & & $1.2 \mathrm{~m}$ & $2.4 \mathrm{~m}$ & $3.7 \mathrm{~m}$ & $4.9 \mathrm{~m}$ & $6.1 \mathrm{~m}$ & \\
\hline 1.5 & 0.5 & 1.7 & 3.3 & 5.0 & 6.6 & 8.3 & 1.7 & 7.5 & 15.0 & 22.5 & 30.0 & 37.5 & 7.5 \\
\hline 2.0 & 0.6 & 2.2 & 4.4 & 6.6 & 8.8 & 11.0 & 2.2 & 10.0 & 20.0 & 30.0 & 40.0 & 50.0 & 10.0 \\
\hline 2.5 & 0.8 & 2.8 & 5.5 & 8.3 & 11.0 & 13.8 & 2.8 & 12.5 & 25.0 & 37.5 & 50.0 & 62.5 & 12.5 \\
\hline 3.0 & 0.9 & 3.3 & 6.6 & 9.9 & 13.2 & 16.5 & 3.3 & 15.0 & 30.0 & 45.0 & 60.0 & 75.0 & 15.0 \\
\hline 3.5 & 1.1 & - & 7.7 & 11.6 & 15.4 & 19.3 & 3.9 & - & 35.0 & 52.5 & 70.0 & 87.5 & 17.5 \\
\hline 4.0 & 1.2 & - & 8.8 & 13.2 & 17.6 & 22.0 & 4.4 & - & 40.0 & 60.0 & 80.0 & 100.0 & 20.0 \\
\hline 4.5 & 1.4 & - & 9.9 & 14.9 & 19.8 & 24.8 & 5.0 & - & 45.0 & 67.5 & 90.0 & 112.5 & 22.5 \\
\hline 5.0 & 1.5 & - & 11.0 & 16.5 & 22.0 & 27.5 & 5.5 & - & 50.0 & 75.0 & 100.0 & 125.0 & 25.0 \\
\hline 5.5 & 1.7 & - & 12.1 & 18.2 & 24.2 & 30.3 & 6.1 & - & 55.0 & 82.5 & 110.0 & 137.5 & 27.5 \\
\hline 6.0 & 1.8 & - & - & 19.8 & 26.4 & 33.0 & 6.6 & - & - & 90.0 & 120.0 & 150.0 & 30.0 \\
\hline 6.5 & 2.0 & - & - & 21.5 & 28.6 & 35.8 & 7.2 & - & - & 97.5 & 130.0 & 162.5 & 32.5 \\
\hline 7.0 & 2.1 & - & - & 23.1 & 30.8 & 38.5 & 7.7 & - & - & 105.0 & 140.0 & 175.0 & 35.0 \\
\hline 7.5 & 2.3 & - & - & 24.8 & 33.0 & 41.3 & 8.3 & - & - & 112.5 & 150.0 & 187.5 & 37.5 \\
\hline 8.0 & 2.4 & - & - & 26.4 & 35.2 & 44.0 & 8.8 & - & - & 120.0 & 160.0 & 199.9 & 40.0 \\
\hline 8.5 & 2.6 & - & - & 28.1 & 37.4 & 46.8 & 9.4 & - & - & 127.5 & 170.0 & 212.4 & 42.5 \\
\hline 9.0 & 2.7 & - & - & - & 39.6 & 49.5 & 9.9 & - & - & - & 180.0 & 224.9 & 45.0 \\
\hline 9.5 & 2.9 & - & - & - & 41.8 & 52.3 & 10.5 & - & - & - & 190.0 & 237.4 & 47.5 \\
\hline 10.0 & 3.0 & - & - & - & 44.0 & 55.0 & 11.0 & - & - & - & 199.9 & 249.9 & 50.0 \\
\hline 10.5 & 3.2 & - & - & - & 46.2 & 57.8 & 11.6 & - & - & - & 209.9 & 262.4 & 52.5 \\
\hline 11.0 & 3.4 & - & - & - & 48.4 & 60.5 & 12.1 & - & - & - & 219.9 & 274.9 & 55.0 \\
\hline 11.5 & 3.5 & - & - & - & - & 63.3 & 12.7 & - & - & - & - & 287.4 & 57.5 \\
\hline 12.0 & 3.7 & - & - & - & - & 66.0 & 13.2 & - & - & - & - & 299.9 & 60.0 \\
\hline 12.5 & 3.8 & - & - & - & - & 68.8 & 13.8 & - & - & - & - & 312.4 & 62.5 \\
\hline 13.0 & 4.0 & - & - & - & - & 71.5 & 14.3 & - & - & - & - & 324.9 & 65.0 \\
\hline 13.5 & 4.1 & - & - & - & - & 74.3 & 14.9 & - & - & - & - & 337.4 & 67.5 \\
\hline 14.0 & 4.3 & - & - & - & - & 77.0 & 15.4 & - & - & - & - & 349.9 & 70.0 \\
\hline
\end{tabular}

Note: the maximum extent of $L$ is determined based on the Coulomb failure wedge of a soil with a friction angle of $20^{\circ}$.

thrust pressure distribution of Peck [6] and slightly more conservative than that of Tschebotarioff [9].

\section{T-L Method Validation}

The T-L method was compared to Coulomb theory, C-80, C-60, and "rule-of-thumb" methods using the same "worstcase" soil range in Table 2 . In the resistance calculations for the T-L, C-80, and C-60 methods, a failure condition $(R<$ $Q_{h}$ ) was not observed irrespective of ground slope. The "ruleof-thumb" method did result in a failure condition for the weakest sandy soil at each $i$.

Table 2 illustrates that the C-80 and C-60 total shoring resistances are approximately double the Coulomb theory resultant and at least 1.75 and 1.33 times greater than the T-L method, respectively. Moreover, the C-80 and C-60 methods require resistances that can exceed the shoring capacity of specialized emergency rescue equipment, e.g., Paratech Rescue Shoring is rated up to 80.0 kips $(355.9 \mathrm{kN})$ and are well in excess of typical timber rescue shoring material.

Table 3 investigates Equations (12) and (13), in terms of a maximum force per strut, compared to the calculated resistance of Equation (10). The calculated maximum thrust force, acting on a $4 \mathrm{ft}(1.25 \mathrm{~m}) \times 4 \mathrm{ft}(1.25 \mathrm{~m})$ section of panelling, does not exceed the per strut resistance of the T-L,
C-80 and C-60 methods. However, both the C-60 and C-80 methods require resistances of at least 2.1 times greater than the maximum thrust force per strut from either Peck [6] or Tschebotarioff [9]. The "rule-of-thumb" method underestimates the maximum thrust force by as much as 1.5 kips $(6.7 \mathrm{kN})$ and could result in shoring failure $[5,6,8,9]$.

The number of struts per shoring panel is limited by the maximum thrust per strut in Table 3. If $n_{\mathrm{s}}$, in Equation (9), is increased to three struts per shoring panel, the resulting $R_{\mathrm{T}-\mathrm{L}}^{\mathrm{s}}$ would be approximately 2.1 kips for a $4 \mathrm{ft}$ trench depth. This is below the maximum strut force for Peck [6] and Tschebotarioff [9], and localized strut failure could reasonably be expected. This undersizing of the strut would continue for all trench depths presented in Table 3. Therefore, the authors suggest the use of only two struts per shoring panel $\left(n_{\mathrm{s}}=2\right.$ in Equation (9)).

\section{Application of Surcharge Loads}

When trench spoil material is located within $L_{i}$, an additional surcharge load should be added to Equation (10). The angle of repose of dumped material creates trench spoil piles uniform in neither shape nor weight distribution (Figure 2) and limits the maximum potential height. Therefore, a geometrically 
TABLE 2: Coulomb earth-pressures versus the total shoring resistance of the T-L method and the C-80 method. Bold values denote a failure condition where the expected resistance is less than the calculated earth-pressure force.

\begin{tabular}{|c|c|c|c|c|c|c|c|c|c|c|c|c|c|c|c|}
\hline \multirow[t]{2}{*}{$\begin{array}{l}\text { Trench } \\
\text { depth }\end{array}$} & \multirow{2}{*}{$\begin{array}{l}\text { Friction } \\
\text { angle, } \phi\end{array}$} & \multirow{2}{*}{$\begin{array}{l}\text { Ground } \\
\text { slope, } i \\
\text { Degree }\end{array}$} & \multirow[t]{2}{*}{$\begin{array}{l}\text { Lateral earth-pressure } \\
\text { coefficient, } k_{a}\end{array}$} & \multicolumn{2}{|c|}{$\begin{array}{l}\text { Bulk unit } \\
\text { weight }\end{array}$} & \multicolumn{2}{|c|}{$\begin{array}{c}\text { Coulomb } \\
\text { earth- } \\
\text { pressure } \\
\text { resultant, } \\
Q_{\mathrm{h}}{ }^{1}\end{array}$} & \multicolumn{2}{|c|}{$R_{\mathrm{T}-\mathrm{L}}^{2}$} & Total & shorin & g resis & tance & \multicolumn{2}{|c|}{$R_{\mathrm{rt}}{ }^{5}$} \\
\hline & & & & pcf & $\mathrm{kN} / \mathrm{m}^{3}$ & kips & $\mathrm{kN}$ & kips & $\mathrm{kN}$ & kips & $\mathrm{kN}$ & kips & $\mathrm{kN}$ & kips & $\mathrm{kN}$ \\
\hline \multirow{8}{*}{$\begin{array}{l}4 \mathrm{ft} \\
(1.2 \mathrm{~m})\end{array}$} & 20 & 0 & 0.49 & 120 & 18.9 & 1.9 & 8.4 & 3.3 & 15.0 & 6.3 & 27.9 & 5.0 & 22.2 & 2.1 & 9.5 \\
\hline & 30 & 0 & 0.33 & 125 & 19.6 & 1.3 & 5.9 & 3.3 & 15.0 & 6.3 & 27.9 & 5.0 & 22.2 & 2.1 & 9.5 \\
\hline & 40 & 0 & 0.22 & 130 & 20.4 & 0.9 & 4.1 & 3.3 & 15.0 & 6.3 & 27.9 & 5.0 & 22.2 & 2.1 & 9.5 \\
\hline & 20 & 12 & 0.60 & 120 & 18.9 & 2.3 & 10.2 & 3.3 & 15.0 & 6.3 & 27.9 & 5.0 & 22.2 & 2.1 & 9.5 \\
\hline & 30 & 12 & 0.38 & 125 & 19.6 & 1.5 & 6.8 & 3.3 & 15.0 & 6.3 & 27.9 & 5.0 & 22.2 & 2.1 & 9.5 \\
\hline & 40 & 12 & 0.24 & 130 & 20.4 & 1.0 & 4.4 & 3.3 & 15.0 & 6.3 & 27.9 & 5.0 & 22.2 & 2.1 & 9.5 \\
\hline & 30 & 30 & 0.75 & 125 & 19.6 & 3.0 & 13.3 & 3.3 & 15.0 & 6.3 & 27.9 & 5.0 & 22.2 & 2.1 & 9.5 \\
\hline & 40 & 30 & 0.32 & 130 & 20.4 & 1.3 & 5.9 & 3.3 & 15.0 & 6.3 & 27.9 & 5.0 & 22.2 & 2.1 & 9.5 \\
\hline \multirow{8}{*}{$\begin{array}{l}8 \mathrm{ft} \\
(2.4 \mathrm{~m})\end{array}$} & 20 & 0 & 0.49 & 120 & 18.9 & 7.5 & 33.5 & 12.1 & 55.0 & 22.8 & 101.3 & 17.7 & 78.6 & 8.5 & 38.0 \\
\hline & 30 & 0 & 0.33 & 125 & 19.6 & 5.3 & 23.5 & 12.1 & 55.0 & 22.8 & 101.3 & 17.7 & 78.6 & 8.5 & 38.0 \\
\hline & 40 & 0 & 0.22 & 130 & 20.4 & 3.7 & 16.3 & 12.1 & 55.0 & 22.8 & 101.3 & 17.7 & 78.6 & 8.5 & 38.0 \\
\hline & 20 & 12 & 0.60 & 120 & 18.9 & 9.2 & 41.0 & 12.1 & 55.0 & 22.8 & 101.3 & 17.7 & 78.6 & 8.5 & 38.0 \\
\hline & 30 & 12 & 0.38 & 125 & 19.6 & 6.1 & 27.0 & 12.1 & 55.0 & 22.8 & 101.3 & 17.7 & 78.6 & 8.5 & 38.0 \\
\hline & 40 & 12 & 0.24 & 130 & 20.4 & 4.0 & 17.8 & 12.1 & 55.0 & 22.8 & 101.3 & 17.7 & 78.6 & 8.5 & 38.0 \\
\hline & 30 & 30 & 0.75 & 125 & 19.6 & 12.0 & 53.4 & 12.1 & 55.0 & 22.8 & 101.3 & 17.7 & 78.6 & 8.5 & 38.0 \\
\hline & 40 & 30 & 0.32 & 130 & 20.4 & 5.3 & 23.7 & 12.1 & 55.0 & 22.8 & 101.3 & 17.7 & 78.6 & 8.5 & 38.0 \\
\hline \multirow{8}{*}{$\begin{array}{l}12 \mathrm{ft} \\
(3.7 \mathrm{~m})\end{array}$} & 20 & 0 & 0.49 & 120 & 18.9 & 16.9 & 75.3 & 28.1 & 127.5 & 49.5 & 220.3 & 38.0 & 169.1 & 19.2 & 85.4 \\
\hline & 30 & 0 & 0.33 & 125 & 19.6 & 11.9 & 52.8 & 28.1 & 127.5 & 49.5 & 220.3 & 38.0 & 169.1 & 19.2 & 85.4 \\
\hline & 40 & 0 & 0.22 & 130 & 20.4 & 8.2 & 36.6 & 28.1 & 127.5 & 49.5 & 220.3 & 38.0 & 169.1 & 19.2 & 85.4 \\
\hline & 20 & 12 & 0.60 & 120 & 18.9 & 20.7 & 92.2 & 28.1 & 127.5 & 49.5 & 220.3 & 38.0 & 169.1 & 19.2 & 85.4 \\
\hline & 30 & 12 & 0.38 & 125 & 19.6 & 13.7 & 60.9 & 28.1 & 127.5 & 49.5 & 220.3 & 38.0 & 169.1 & 19.2 & 85.4 \\
\hline & 40 & 12 & 0.24 & 130 & 20.4 & 9.0 & 40.0 & 28.1 & 127.5 & 49.5 & 220.3 & 38.0 & 169.1 & 19.2 & 85.4 \\
\hline & 30 & 30 & 0.75 & 125 & 19.6 & 27.0 & 120.1 & 28.1 & 127.5 & 49.5 & 220.3 & 38.0 & 169.1 & 19.2 & 85.4 \\
\hline & 40 & 30 & 0.32 & 130 & 20.4 & 12.0 & 53.3 & 28.1 & 127.5 & 49.5 & 220.3 & 38.0 & 169.1 & 19.2 & 85.4 \\
\hline \multirow{8}{*}{$\begin{array}{l}16 \mathrm{ft} \\
(4.9 \mathrm{~m})\end{array}$} & 20 & 0 & 0.49 & 120 & 18.9 & 30.1 & 133.9 & 48.4 & 219.9 & 86.5 & 384.9 & 66.0 & 293.8 & 34.1 & 151.8 \\
\hline & 30 & 0 & 0.33 & 125 & 19.6 & 21.1 & 93.9 & 48.4 & 219.9 & 86.5 & 384.9 & 66.0 & 293.8 & 34.1 & 151.8 \\
\hline & 40 & 0 & 0.22 & 130 & 20.4 & 14.6 & 65.1 & 48.4 & 219.9 & 86.5 & 384.9 & 66.0 & 293.8 & 34.1 & 151.8 \\
\hline & 20 & 12 & 0.60 & 120 & 18.9 & 36.9 & 164.0 & 48.4 & 219.9 & 86.5 & 384.9 & 66.0 & 293.8 & 34.1 & 151.8 \\
\hline & 30 & 12 & 0.38 & 125 & 19.6 & 24.3 & 108.2 & 48.4 & 219.9 & 86.5 & 384.9 & 66.0 & 293.8 & 34.1 & 151.8 \\
\hline & 40 & 12 & 0.24 & 130 & 20.4 & 16.0 & 71.1 & 48.4 & 219.9 & 86.5 & 384.9 & 66.0 & 293.8 & 34.1 & 151.8 \\
\hline & 30 & 30 & 0.75 & 125 & 19.6 & 48.0 & 213.5 & 48.4 & 219.9 & 86.5 & 384.9 & 66.0 & 293.8 & 34.1 & 151.8 \\
\hline & 40 & 30 & 0.32 & 130 & 20.4 & 21.3 & 94.7 & 48.4 & 219.9 & 86.5 & 384.9 & 66.0 & 293.8 & 34.1 & 151.8 \\
\hline \multirow{8}{*}{$\begin{array}{l}20 \mathrm{ft} \\
(6.1 \mathrm{~m})\end{array}$} & 20 & 0 & 0.49 & 120 & 18.9 & 47.0 & 209.2 & 77.0 & 349.9 & 133.8 & 595.0 & 101.8 & 452.7 & 53.3 & 237.2 \\
\hline & 30 & 0 & 0.33 & 125 & 19.6 & 33.0 & 146.8 & 77.0 & 349.9 & 133.8 & 595.0 & 101.8 & 452.7 & 53.3 & 237.2 \\
\hline & 40 & 0 & 0.22 & 130 & 20.4 & 22.9 & 101.8 & 77.0 & 349.9 & 133.8 & 595.0 & 101.8 & 452.7 & 53.3 & 237.2 \\
\hline & 20 & 12 & 0.60 & 120 & 18.9 & 57.6 & 256.2 & 77.0 & 349.9 & 133.8 & 595.0 & 101.8 & 452.7 & 53.3 & 237.2 \\
\hline & 30 & 12 & 0.38 & 125 & 19.6 & 38.0 & 169.0 & 77.0 & 349.9 & 133.8 & 595.0 & 101.8 & 452.7 & 53.3 & 237.2 \\
\hline & 40 & 12 & 0.24 & 130 & 20.4 & 25.0 & 111.0 & 77.0 & 349.9 & 133.8 & 595.0 & 101.8 & 452.7 & 53.3 & 237.2 \\
\hline & 30 & 30 & 0.75 & 125 & 19.6 & 75.0 & 333.6 & 77.0 & 349.9 & 133.8 & 595.0 & 101.8 & 452.7 & 53.3 & 237.2 \\
\hline & 40 & 30 & 0.32 & 130 & 20.4 & 33.3 & 148.0 & 77.0 & 349.9 & 133.8 & 595.0 & 101.8 & 452.7 & 53.3 & 237.2 \\
\hline
\end{tabular}

${ }^{1}$ Coulomb resultant is calculated for the width of a standard shoring panel: $4 \mathrm{ft}(1.2 \mathrm{~m}) .{ }^{2} R_{\mathrm{T}-\mathrm{L}}$ is calculated at the maximum $L$ to be comparable to Coulomb earth-pressure calculations. ${ }^{3}$ The $\mathrm{C}-80$ method requires that the top of the shoring support the same pressure as the bottom of the shoring, i.e., a uniform pressure distribution based on the maximum lateral earth pressure, thereby multiplying the earth-pressure by a minimum factor of approximately 2.0 . ${ }^{4} \mathrm{C}-60$ material is explained in Martinette [1] and in OSHA [3] where the $c=60$ in Equation (2). OSHA [3] explicitly states that this material should not be used as the "worst case" soil. ${ }^{5}$ The "rule-of-thumb," Equation (2), is commonly used by first responders based on Martinette [1]. Bold values denote a failure scenario.

simplified uniform equivalent surcharge height, $h_{\mathrm{s}}^{\mathrm{e}}$, as a function of $L_{i}$ (assumes an angle of repose, $\alpha=30^{\circ}$ ) is

$$
h_{\mathrm{s}}^{\mathrm{e}}=0.5 \tan (\alpha) L_{i}=0.289 L_{i} \text {. }
$$

Dumped sandy material will stabilize about the angle of repose at a unit weight of between $80 \mathrm{pcf}\left(12.6 \mathrm{kN} / \mathrm{m}^{3}\right)$ and $100 \mathrm{pcf}\left(15.7 \mathrm{kN} / \mathrm{m}^{3}\right)$ and increase in volume by approximately a third [4]. Therefore, the "worst-case" spoil material unit weight, $\gamma_{s}$, is assumed $100 \mathrm{pcf}\left(15.7 \mathrm{kN} / \mathrm{m}^{3}\right)$ based on $\gamma_{\mathrm{T}-\mathrm{L}}$. The surcharge force per strut, $S_{\mathrm{s}}$, is calculated as

$$
S_{\mathrm{s}}=k_{0} \gamma_{\mathrm{s}} h_{\mathrm{s}}^{e} w L_{i}= \begin{cases}0.1 L_{\mathrm{ft}}^{2}, & (\mathrm{kips}), \\ 2.7 L_{m}^{2}, & (\mathrm{kN}) .\end{cases}
$$




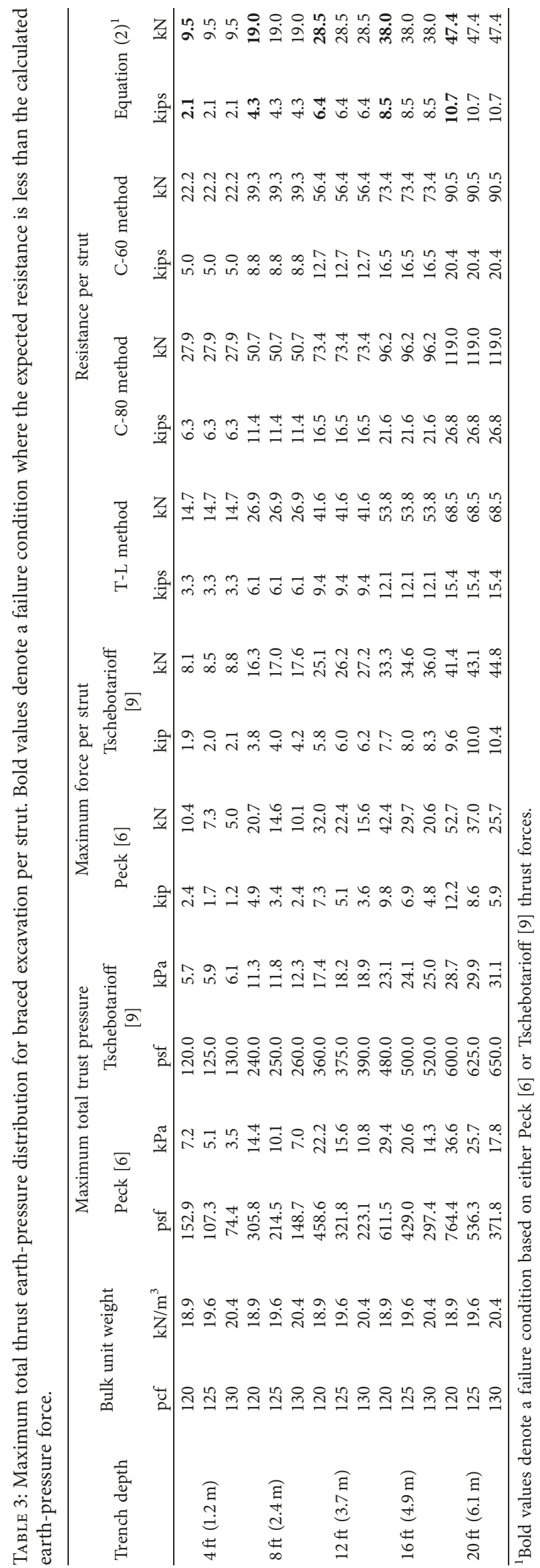




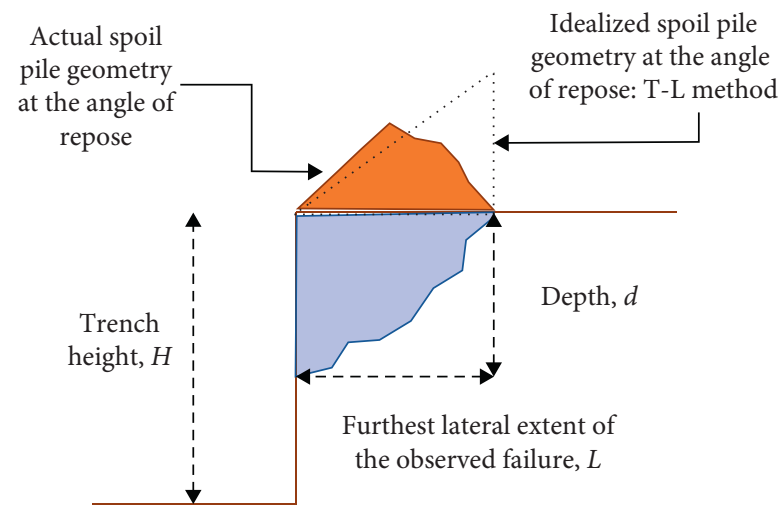

Figure 2: Spoil pile geometry at the angle of repose. The idealized geometry is conservatively used in the T-L method for calculation of surcharge loads.

TABLE 4: Use of the T-L method for different failure scenarios. The clay properties bracket the range of plausible Type C clays that can exhibit the observed failure geometry.

\begin{tabular}{|c|c|c|c|c|c|c|c|c|}
\hline & \multicolumn{4}{|c|}{ Scenario 1: Figure 3} & \multicolumn{4}{|c|}{ Scenario 2: Figure 4} \\
\hline & Silty sand & Sand & Clay & Clay & Sand & Sand & Clay & Clay \\
\hline Relative strength classification & $\begin{array}{l}\text { Meduim } \\
\text { dense }\end{array}$ & Dense & $\begin{array}{l}\text { Medium } \\
\text { stiff }\end{array}$ & Soft & Dense & Loose & $\begin{array}{l}\text { Medium } \\
\text { stiff }\end{array}$ & Soft \\
\hline Relative saturation classification & Moist & Saturated & Saturated & Saturated & $\begin{array}{l}\text { Moist- } \\
\text { dry }\end{array}$ & Saturated & Saturated & Saturated \\
\hline Undrained shear stength, $S_{\mathrm{u}}(\mathrm{psf})$ & - & - & 325 & 100 & - & - & 650 & 200 \\
\hline Active earth pressure coefficient, $k_{\mathrm{a}}$ & 0.33 & 0.33 & 1 & 1 & 0.33 & 0.33 & 1 & 1 \\
\hline Unit weight, $\gamma$ (pcf) & 125 & 133 & 110 & 100 & 130 & 125 & 110 & 100 \\
\hline Maximum $L(\mathrm{ft})$ & 3 & 3 & 3 & 3 & 9 & 9 & 9 & 9 \\
\hline$w(\mathrm{ft})$ & 5 & 5 & 5 & 5 & 6 & 6 & 6 & 6 \\
\hline$H(\mathrm{ft})$ & 6 & 6 & 6 & 6 & 12 & 12 & 12 & 12 \\
\hline \multicolumn{9}{|l|}{ Coulomb earth pressure } \\
\hline$P_{\mathrm{a}}=(1 / 2) \gamma H^{2} k_{\mathrm{a}}-2 c H \sqrt{\left(k_{\mathrm{a}}\right)}(\mathrm{psf})$ & 742.5 & 790.02 & 30 & 1200 & 3088.8 & 2970 & 120 & 4800 \\
\hline$Q=w P_{\mathrm{a}}$ (kips) & 3.7 & 4.0 & 0.2 & 6.0 & 18.5 & 17.8 & 0.7 & 28.8 \\
\hline \multicolumn{9}{|l|}{ T-L method: } \\
\hline$R_{\mathrm{T}-\mathrm{L}}^{s}=1.1 \mathrm{~L}_{\mathrm{ft}}(\mathrm{kips})$ & 3.3 & 3.3 & 3.3 & 3.3 & 9.9 & 9.9 & 9.9 & 9.9 \\
\hline$N$ & 4 & 4 & 4 & 4 & 6 & 6 & 6 & 6 \\
\hline$R_{\mathrm{T}-\mathrm{L}}=n R_{\mathrm{T}-\mathrm{L}}^{\mathrm{s}}$ (kips) & 13.2 & 13.2 & 13.2 & 13.2 & 59.4 & 59.4 & 59.4 & 59.4 \\
\hline \multicolumn{9}{|c|}{$\begin{array}{l}\text { Maximum braced excavation pressure per } \\
\text { strut [6]: }\end{array}$} \\
\hline Sand: & & & & & & & & \\
\hline$P=0.65 \gamma H k_{\mathrm{a}}(\mathrm{psf})$ & 160.9 & 171.2 & & & 334.6 & 321.8 & & \\
\hline \multicolumn{9}{|l|}{ Clay: } \\
\hline$\gamma H / S_{\mathrm{u}}$ & & & 2.0 & 6.0 & & & 2.0 & 6.0 \\
\hline \multicolumn{9}{|l|}{$\gamma H / S_{\mathrm{u}}<4$} \\
\hline$P=0.3 \gamma H(\mathrm{psf})$ & & & 198.0 & & & & 396.0 & \\
\hline \multicolumn{9}{|l|}{$\gamma H / S_{\mathrm{u}}>4$} \\
\hline$P=\gamma H-4 S_{\mathrm{u}}(\mathrm{psf})$ & & & & 200.0 & & & & 400.0 \\
\hline$Q_{\max }=P \times 4 \mathrm{ft} \times 4 \mathrm{ft}($ kip per strut $)$ & 2.6 & 2.7 & 3.2 & 3.2 & 5.4 & 5.1 & 6.3 & 6.4 \\
\hline
\end{tabular}

\section{Use of the T-L Method in Trench Rescue Scenarios}

To illustrate the use of the T-L method, two actual failure scenarios are given in conjunction with three possible soil properties for the observed failure geometry, Table 4, to illustrate the T-L method's applicability to rescue shoring operations where soil properties are unknown. It is noted that other combinations of mechanical properties are possible in theory only as such combinations are not plausible for the observed failures or trench excavation, e.g., a very soft cohesive material $\left(\gamma=100\right.$ pcf and $S_{\mathrm{u}}=$ $100 \mathrm{psf}$ ) would not be plausible for a wedge failure at $12 \mathrm{ft}$ as the trench would undergo a heave failure $((\gamma H) / c>8.0)$ as per Peck [6] at a depth of $8 \mathrm{ft}$ even if braced during excavation. To back-calculate the actual failure pressures, $H$ in Equations (3), (12), and (13) are taken as the depth of the failed section. This is necessary to account for the site 


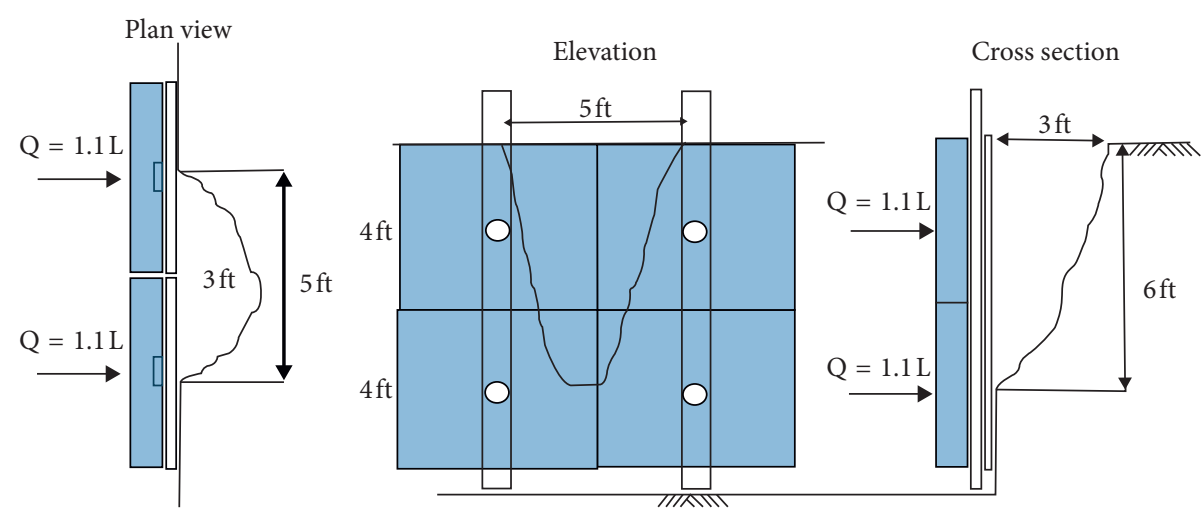

Figure 3: Scenario 1: failure geometry and emergency rescue shoring layout. Note that the panel placement shown is not ideal for actual rescue operations but demonstrates minimum necessary calculations.

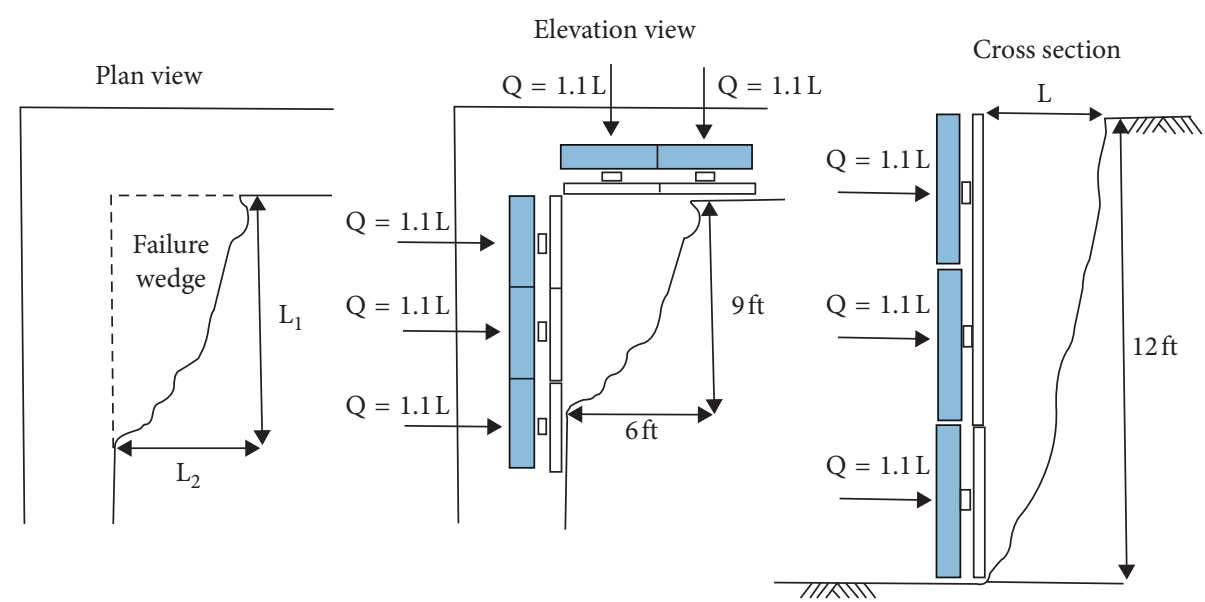

FIGURE 4: Scenario 2: failure geometry and emergency rescue shoring layout. Note that the panel placement shown is not ideal for actual rescue operations but demonstrates minimum necessary calculations.

heterogeneity and variability not considered within Equations (3), (12), and (13).

Figure 3 shows the plan, elevation, and cross-sectional views of the failure within a $10 \mathrm{ft}$ trench with no surcharge loads within $3 \mathrm{ft}$ of the trench face. Unlike the predicted Coulomb and Peck failure wedge pressure diagrams, used for derivations of Equations (3) and (12), respectively, the actual failure is a reduced size due to in situ soil heterogeneity. The lateral earth pressure calculations for this scenario are tabulated in Table 4 for the T-L method and the actual soil material (a moist, loose to medium dense, silty sand: column 1 in Table 4). In all scenarios, the calculated resistance for a single rescue shoring panel (where $n=4$, Figure 3), Equations (10) and (11), were greater than the Coulomb earth pressures and the maximum excavation thrust pressures [6].

The second scenario, Figure 4, depicts a trench corner failure. The actual soil condition in this case is a dense dry to moist sand (column 5 in Table 4). The maximum lateral extent of the failure, $L_{\mathrm{ft}}$, is $9 \mathrm{ft}$, and the number of struts, $n$, is taken as the number of struts on the shortest braced section, i.e., $n=6$ as the shortest braced section in Figure 4 is two panel widths at three struts per panel width. Similar to the previous scenario, no surcharge loads are located within $L_{\mathrm{ft}}$ of the trench. It should be noted that the undrained shear strength used in scenario 2 is greater that in scenario 1 . This is due to a $S_{\mathrm{u}}$ of $200 \mathrm{psf}$ being the minimum $S_{\mathrm{u}}$ that will exhibit a wedge failure as shown in Figure 4 versus a heave failure of the trench bottom. As with the previous scenario, the resistance calculated via the $\mathrm{T}$-L method was greater than the Coulomb earth pressures and the maximum excavation thrust pressures of the failed section.

Table 4 illustrates that the Peck [6] thrust pressures govern the overall stability of the rescue shoring design. In neither scenario was the resistance calculated by the T-L method exceeded; however, for the worst possible cohesive case, i.e., soft saturated clay in scenario 1, the factor of safety is 1.03 . For permanent braced excavation, this value would be problematic; however. rescue shoring is a temporary and continually monitored braced system. Therefore, temporary braced excavation calculations (e.g., [9]) are more appropriate but are lower in magnitude than permanent braced excavation pressures [6]. Tschebotarioff's [9] temporary excavation thrust pressures for soft cohesive soil, scenario 1, would result in an acceptable factor of safety of 1.63. Thus, if the calculated $R_{\mathrm{T}-\mathrm{L}}^{s}$ value, Equation (10), is greater than the permanent braced excavation pressures [6], the system will have an adequate factor of safety for emergency operations. 


\section{Conclusions}

Emergency trench shoring design for rescue operations has no reliable standard for determining lateral earth pressures. A new simplified method, the T-L method, has been derived to calculate the realistic "worst-case" earth pressures for emergency rescue operations and especially for use by first responders who may not be qualified to assess soil types and mechanical properties. The T-L method was validated against the holistic Coulomb theory and for strut thrust resistance for permanent and temporary braced excavations.

The T-L method accounts for the destabilizing effects through the use of an actual maximum lateral failure extent. This reduces the required force per strut, thus decreasing the material and time requirements for installing emergency trench rescue shoring operations. Moreover, first responders only need to measure only one on-site property, the furthest lateral extent of the observed failure, to quantify the resistances needed for a rescue operation.

\section{Data Availability}

Previously published mechanical property, strength behavior, and saturation characteristic data were used to support this study. These prior studies (and subsequent datasets) are cited at relevant places within the text.

\section{Conflicts of Interest}

The authors declare that they have no conflicts of interest.

\section{Acknowledgments}

The authors gratefully acknowledge D. Barrier, J. Gergely, C. Dashner, and R. Zawlocki for their invaluable insights, support, and reviews of the presented method. The research was based on technical data funded by the Assistant Secretary of the Army (Acquisition, Logistics, and Technology (ASA(ALT))) under 62784/T40/46 and 61102/T22/01. Permission to publish was granted by Director, Geotechnical and Structures Laboratory, US Army Engineer Research and Development Center, with unlimited distribution.

\section{References}

[1] C. V. Martinette Jr., Trench Rescue: Awareness, Operations, Technicians, Jones and Bartlett Publishers, Inc, Mississauga, ON, Canada, 2nd edition, 2008.

[2] Occupational Safety and Health Administration (OSHA), Safety Health Regulations for Construction-Excavations: 1926 Subpart $P$, US Department of Labor, Occupational Safety and Health Administration, Washington, DC, USA, 1989.

[3] Occupational Safety and Health Administration (OSHA), Standards Interpretation-Soil Classification. Interpretation Letter, R. F. Gurnham, Ed., US Department of Labor, Occupational Safety and Health Administration, Washington, DC, USA, 1994.

[4] J. E. Bowles, Foundation Analysis and Design, McGraw Hill, Inc, New York, NY, USA, 4th edition, 1988.
[5] T. W. Lambe and R. V. Whitman, Soil Mechanics, John Wiley \& Sons, New York, NY, USA, 1969.

[6] R. B. Peck, "Deep excavations and tunneling in soft ground," in Proceedings of the 7th International Conference on Soil Mechanics and Foundation Engineering, pp. 225-290, Mexico City, Mexico, August 1969.

[7] R. Salgado, The Engineering of Foundations, McGraw Hill, Inc, New York, NY, USA, 2008.

[8] K. Terzaghi and R. B. Peck, Soil Mechanics in Engineering Practice, John Wiley \& Sons, New York, NY, USA, 2nd edition, 1967.

[9] G. P. Tschebotarioff, Foundations, Retaining and Earth Structures, McGraw-Hill, New York, NY, USA, 2nd edition, 1973.

[10] O.-D. S. Taylor, K. E. Winters, A. L. Cunningham, and R. E. Walker, "Cohesionless soil fabric behavior at low confining pressures," in Proceedings of 19th International Conference on Soil Mechanics and Geotechnical Engineering, pp. 1-4, Seoul, South Korea, September 2017.

[11] O.-D. S. Taylor, K. E. Winters, W. W. Berry, L. A. Walshire, and P. G. Kinnebrew, "Near-Surface soils: self-supported unconfined drained sand specimens," Canadian Geotechnical Journal, 2018.

[12] B. K. Hough, Basic Soils Engineering, Ronald Press, New York, NY, USA, 1957.

[13] G. C. Cho and J. C. Santamarina, "Unsaturated particulate material-particle-level studies," Journal of Geotechnical and Geoenvironmental Engineering, vol. 127, no. 1, pp. 84-96, 2001.

[14] P. W. Rowe, "The stress-dilatancy relation for static equilibrium of an assembly of particles in contact," Proceedings of the Royal Society A: Mathematical, Physical and Engineering Sciences, vol. 269, no. 1339, pp. 500-527, 1962.

[15] K. Terzaghi and R. B. Peck, Soil Mechanics in Engineering Practice, John Wiley \& Sons, New York, NY, USA, 1948.

[16] K. E. Winters, O. D. S. Taylor, W. W. Berry, W. R. Rowland, M. D. Antwine, and A. L. Cunningham, "Cohesionless soil fabric and shear strength at low confining pressures," ASCE GeoChicago, vol. 272, pp. 212-221, 2016.

[17] C. A. Coulomb, Essai Sur Une Application des Regles des Maximis et Minimi A Quelques Problemes de Statique Relatifs A L'Architecture, Memoirs Academic Royale des Science Press (par Divers Savants), Vol. 7, Memoirs Academic Royale des Science Press (par Divers Savants), Paris, France, 1776.

[18] R. Lancellotta, "Analytical solution of passive earth pressure," Geotechnique, vol. 52, no. 8, pp. 617-619, 2002.

[19] K. Paik and R. Salgado, "Arching effects on active earth pressure on retaining walls," Geotechnique, vol. 53, no. 7, pp. 643-653, 2003.

[20] J. T. Blackburn and R. J. Finno, "Three-dimensional responses observed in an internally braced excavation in soft clay," Journal of Geotechnical and Geoenvironmental Engineering, vol. 133, no. 11, pp. 1364-1373, 2007.

[21] K. Karlsrud and L. Andresen, "Loads on braced excavations in soft clays," International Journal of Geomechanics, vol. 5, no. 2, pp. 107-113, 2005.

[22] J. B. Wang, "Strut loads prediction-empirical approach vs geotechnical program solution," in Proceedings of Third International Conference on Soft Soil Engineering, C. F. Lee and Y. Lee, Eds., Hong Kong Polytechnic University, Taylor and Francis, Hong-Kong, China, December 2001. 
[23] F. Y. Yokel, Soil Classification for Construction Practice in Shallow Trenching, NBS Building Science Series-127, National Bureau of Standards (NBS) for Occupational Safety and Health Administration, Gaithersburg, MD, USA, June 1979.

[24] S. M. LaBaw and M. S. Aggour, "Earth pressures in trench rescue shoring systems," International Journal of Geotechnical Engineering, vol. 6, no. 3, pp. 297-308, 2012.

[25] S. M. LaBaw, Earth pressure determination in trench rescue shoring systems, Ph.D. thesis, University of Maryland, College Park, MD, USA, 2009. 


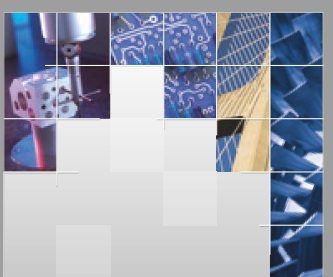

\section{Enfincering}
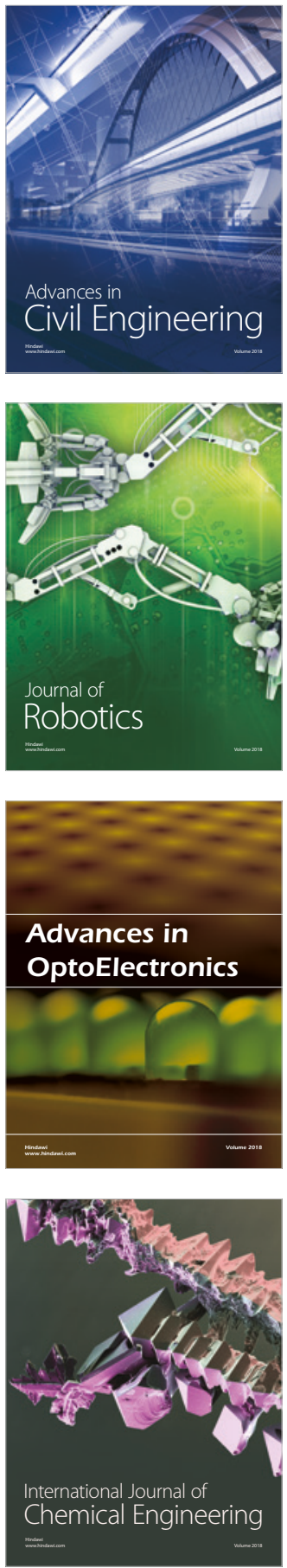

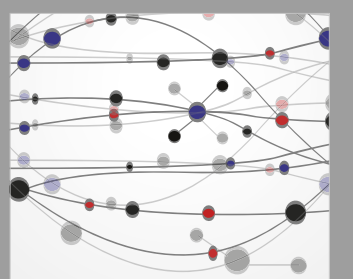

\section{Rotating \\ Machinery}

The Scientific World Journal

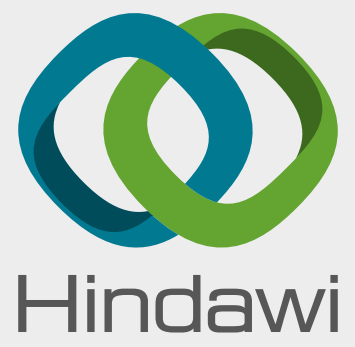

Submit your manuscripts at

www.hindawi.com
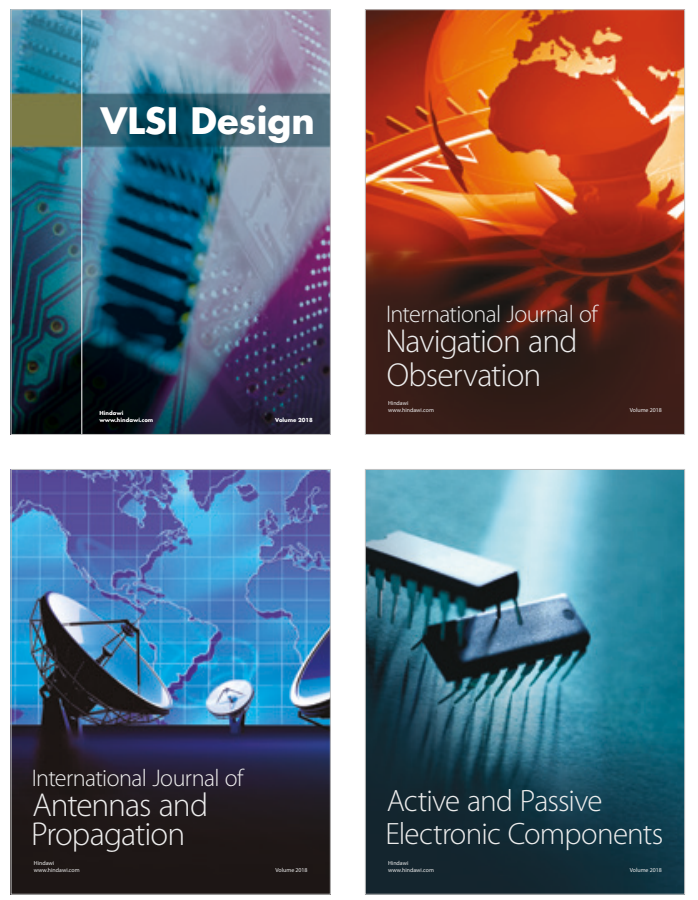
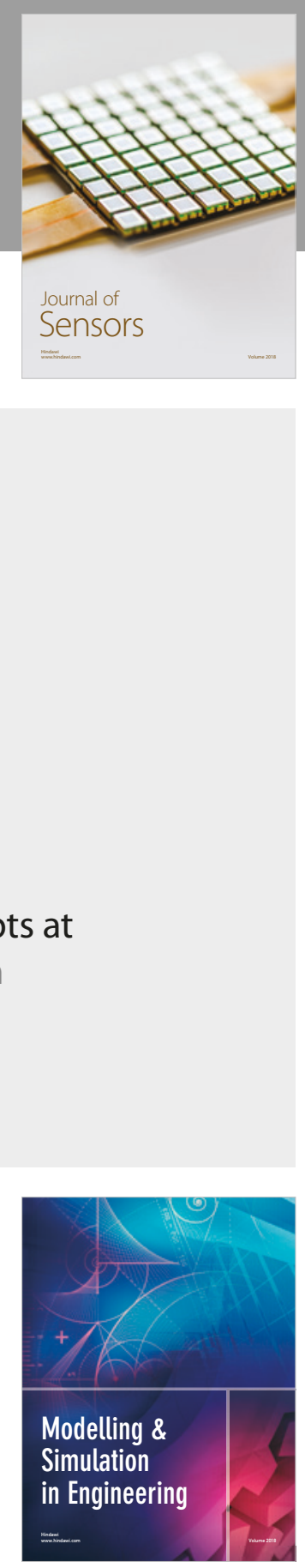

\section{Advances \\ Multimedia}
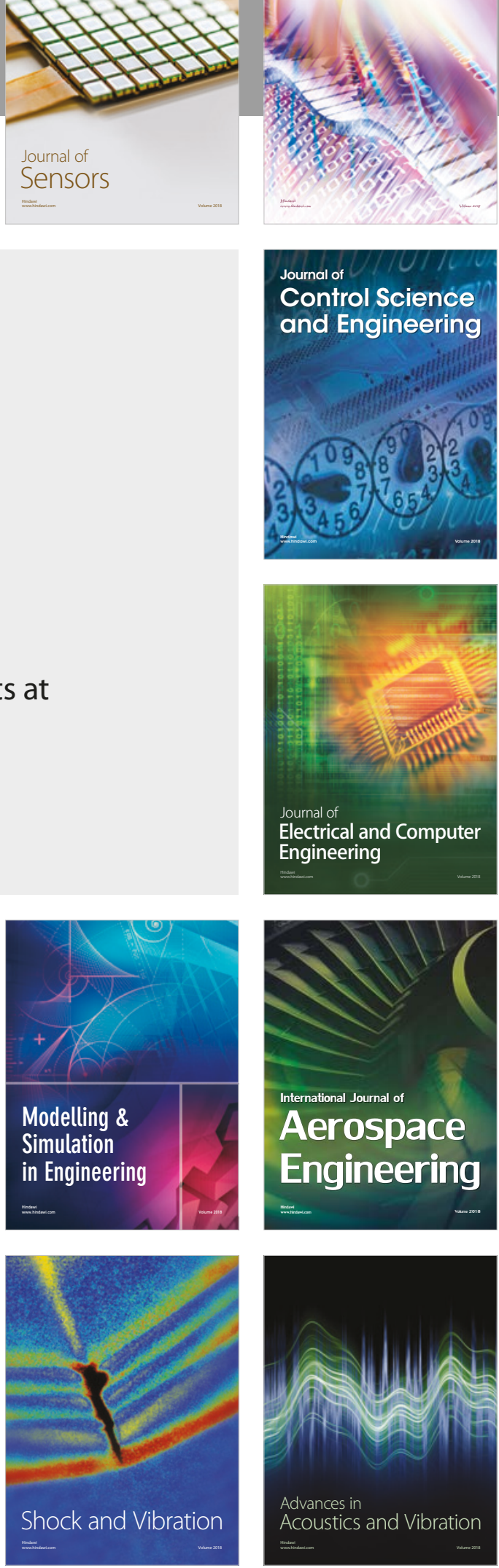